OPEN ACCESS

Edited by:

Dr. Saumen Kumar Maitra

Visva-Bharati University, India

Reviewed by:

Gregoy Y. Bedecarrats, University of Guelph, Canada Vinod Kumar,

University of Delhi, India

*Correspondence:

Jian Li

lijiannp@163.com

Caiqiao Zhang

cqzhang@zju.edu.cn

Specialty section:

This article was submitted to Experimental Endocrinology,

a section of the journal

Frontiers in Endocrinology

Received: 12 April 2018

Accepted: 09 July 2018

Published: 30 July 2018

Citation:

Liu L, Zhang S, Bao J, He X, Tong D, Chen C, Ying $Q$, Zhang Q, Zhang C and $\mathrm{LiJ} \mathrm{(2018)} \mathrm{Melatonin} \mathrm{Improves}$ Laying Performance by Enhancing Intestinal Amino Acids Transport in Hens. Front. Endocrinol. 9:426. doi: $10.3389 /$ fendo.2018.00426

\section{Melatonin Improves Laying Performance by Enhancing Intestinal Amino Acids Transport in Hens}

\author{
Lijuan Liu ${ }^{1}$, Siyu Zhang ${ }^{1}$, Jiayang Bao ${ }^{1}$, Xiaowen $\mathrm{He}^{1}$, Danni Tong ${ }^{1}$, Cong Chen ${ }^{2}$, \\ Qingxiang Ying ${ }^{3}$, Qing Zhang ${ }^{2}$, Caiqiao Zhang ${ }^{1 *}$ and Jian $\mathrm{Li}^{{ }^{1 *}}$
}

${ }^{1}$ Department of Veterinary Medicine, College of Animal Sciences, Zhejiang University, Hangzhou, China, ${ }^{2}$ Yanping Bureau of Animal Husbandry, Veterinary \& Aquatic Products, Nanping, China, ${ }^{3}$ Nanping Bureau of Agriculture, Nanping, China

The high concentration of melatonin (MEL) in the intestinal mucosa suggests that it has a special physiological function in intestine. In hens, previous studies have shown that MEL treatment promoted egg-laying performance. Considering the importance of amino acids (AA) for egg formation, we hypothesized that MEL may enhance the intestinal absorption of AA from the feed, thus promoting egg laying performance. In this study, we supplemented the hens with MEL for two consecutive weeks. The results showed that, compared with control group, feeding with $0.625 \mathrm{mg} \mathrm{MEL} / \mathrm{kg}$ diets gave rise to higher egg laying rate (by $4.3 \%, P=0.016$ ), increased eggshell thickness (by $16.9 \%$, $P<0.01$ ) and albumen height (by $4.5 \%, P=0.042$ ). Meanwhile, feeding with 0.625 and $2.5 \mathrm{mg} \mathrm{MEL/kg} \mathrm{diets} \mathrm{could} \mathrm{significantly} \mathrm{increase} \mathrm{serum} \mathrm{levels} \mathrm{of} \mathrm{aspartic} \mathrm{acid,} \mathrm{threonine,}$ serine, glutamic acid, glycine, alanine, isoleucine, leucine, tyrosine, phenylalanine, lysine, histidine, arginine, and proline. Furthermore, a $0.625 \mathrm{mg} \mathrm{MEL} / \mathrm{kg}$ diets could significantly increase the expression of PepT1 (by 3949.9\%), $B^{0} A T$ (by 6045.9\%), b $b^{0,+} A T$ (by $603.5 \%$ ), and EAAT3 (by $412.7 \%$ ) in the jejunum. Additionally, in the cultured intestinal crypt "organoids," treatment with $0.5 \mu \mathrm{M}$ MEL could significantly enhance the expression of PepT1, $b^{0,+}$ AT and EAAT3 mRNAs by $35.4 \%, 110.0 \%$, and $160.1 \%$, respectively. Detection of MEL concentration in serum and intestinal fluid suggested that lower dosage of MEL feeding was mainly acted on intestine locally, and further increased intestinal antioxidases (GPX-3, SOD-1 or PRDX-3) mRNA expression. Taken together, we demonstrated that MEL feeding in laying hens could locally promote the expression and function of AA transporter in small intestine by up-regulating antioxidases expression, and finally elevate laying performance.

Keywords: melatonin, laying, intestine, amino acids, transporter, hens

\section{INTRODUCTION}

Melatonin (MEL) is mainly produced by the pineal gland. In vertebrates, the MEL level in the intestinal mucosa exceeds its level in the blood plasma by 100 to 400 fold $(1,2)$. This has led to the notion that there is a distinct physiological function of MEL in the intestines. The highest serum MEL level occurs at midnight and is lowest at midday. However, the secretion of intestinal MEL by the mucosal enteroendocrine cells seems to occur without any evident circadian pattern (3). Interestingly, increased levels of intestinal MEL appear to be linked to 
food intake rather than photoperiod (4). Moreover, release of intestinal MEL was also related to the periodicity of food intake (5). Importantly, previous studies have demonstrated that MEL could attenuate lipopolysaccharide-induced chicken's small intestine inflammation (6), promote chicken's intestinal mucosal renewal (7), and improve rat's duodenal barrier functions (8). In the aspect of laying performance, MEL treatment could considerably improve egg weight (9), increase the egg-laying rate and reduce the rate of appearance of sharpei eggs in hens (10). Despite these significant findings, the mechanism of MEL's effects on egg production remains unknown.

During the peak laying period, large amount of egg white, and egg yolk formation requires a plentiful nutrition supply. In the small intestine, protein can only be absorbed in the form of amino acids (AA) or, more marginally, di-peptides, tri-peptides, and. Fisher and Johnson (1956) stated that Arg (arginine), His (histidine), Ile (isoleucine), Leu (leucine), Lys (lysine), Met (methionine), Phe (phenylalanine), Thr (threonine), Trp (tryptophan), and Val (valine) are necessary for protein synthesis during egg formation (11). It was noted that Glu (glutamic acid), is particularly essential for maximum egg production (11). Moreover, $0.2 \% \mathrm{~L}$-Thr supplementation was found to markedly increase laying rate and egg weight (12) and dietary Lys and Ile were necessary for maximum egg production (13). Arg-silicateinositol complex supplementation increased egg production, egg weight, shell weight, and shell thickness during the laying peak period (14). Interestingly, MEL could restore dextran sodium sulfate (DSS)-induced decreasing of Glu and Cys in mice serum (15). However, whether it was AA transported by enterocytes that mediated the MEL effect on egg laying and egg quality remained unknown.

The absorption of AA is dependent on the activities of AA transporters which are located at the enterocytes. APN (Aminopeptidase $\mathrm{N}$ ), an exopeptidase that cleaves AA from the $\mathrm{N}$-terminus of peptides, occurs at the brush border membrane of the enterocytes (16). PepT1, a peptide transporter, can transport di- and tri-peptides from intestinal lumen into enterocytes (17). $\mathrm{B}^{0} \mathrm{AT}\left(\mathrm{B}^{0}\right.$-type $\mathrm{AA}$ transporter), and $\mathrm{b}^{0,+} \mathrm{AT}\left(\mathrm{b}^{0,+}\right.$-type $\mathrm{AA}$ transporter) are responsible for up-taking neutral and cationic AA such as Gly, Ser, Thr, Cys, Tyr, Asn, Gln, His, Lys and Arg (18). EAAT3 (excitatory AA transporter) mainly transports aspartate and glutamate (19). $\mathrm{y}^{+} \mathrm{LAT} 1\left(\mathrm{y}^{+} \mathrm{L}\right.$ AA transporter), is the transporter of Leu, large hydrophobic neutral AA and cationic AA. At the basolateral membrane of the enterocyte, CAT1 (cationic AA transporter 1) and CAT2 can transport cationic AA from the enterocytes into vascular circulation (20). Before hatching, the expression of $A P N, P e p T 1$ and EAAT3 in the chicken intestine is increased from the embryo 15 (E15) stage to that of E21, while CAT1 expression in intestine increases until E17 and then decreases (21). In the chicken, levels of PepT1 mRNA were higher in the duodenum while EAAT3, $b^{0,+} A T$, rBAT, $B^{0} A T$, LAT1, CAT2, and APN mRNA were higher in the ileum, 14 day posthatching (22). The brush border membrane transporters (such as EAAT3 and PepT1) showed increased expression after hatching in chickens (22-24). Interestingly, MEL injection i.p. could promote $B^{0} A T$ and EAAT3 mRNAs expression in young chicken's small intestine (7). However, which
AA transporter plays a critical role during the promotion of MEL on laying property is unclear.

The expression of AA transporters can be influenced by many adverse factors, including those of pathogenic microorganisms and oxidative impairment. In chickens, Eimeria praecox challenge can cause the down-regulation of CAT1, EAAT3, LAT1, and PepT1 in the duodenum, down-regulation of $B^{0} A T$ and $C A T 1$ in the jejunum, and down-regulation of LAT1 in the ileum (25). Lipid peroxidation can significantly decrease the transportation of AA by enterocyte brush border membrane vesicles (26). Oxidative injury was also noted to decrease PepT1 transport velocity in Caco-2 cells (27). Of note, antioxidant enzyme cascades GPx (glutathione peroxidase) and SOD (superoxide dismutase) act as the first line of protection in counteracting ROS (reactive oxygen species) generation, antioxidant protein PRDX (peroxiredoxin) could protect cells against oxidative damage from ROS. Previously studies showed that MEL can also act to up-regulate the expression of SOD1 and the GPX-4 gene in immature bovine oocytes (28) or enhance CAT (catalase), GPx, SOD gene expression in the human skin (29). The antioxidant properties of MEL can, for example, restore menadione induced chicken intestinal calcium absorption alterations (30). However, whether intestinal antioxidant defense system can be enhanced during the promotion of MEL on laying property needs to be clarified.

In the present study we elucidate the effect of MEL on hens laying property and egg quality, and screen the key intestinal AA transporter related to laying performance. We also further evaluate the role and possible pathways of MEL act on the expression and function of laying property related intestinal AA transporters.

\section{MATERIALS AND METHODS}

\section{Animal Husbandry and Experimental Design}

A total of 200 HyLine Brown hens at the peak period of laying were randomly divided into four groups (control, $0.625 \mathrm{mg}$ $\mathrm{MEL} / \mathrm{kg}$ diets, $2.5 \mathrm{mg} \mathrm{MEL} / \mathrm{kg}$ diets, and $10 \mathrm{mg} \mathrm{MEL} / \mathrm{kg}$ diets groups, 50 hens/group). These were fed with basal diets (control group) or basal diets containing MEL at the corresponding $0.625,2.5$ and $10 \mathrm{mg} / \mathrm{kg}$ diets, respectively, for 2 weeks. The composition and nutrient level of the basal diets is listed in Table 1. The MEL dosages chosen in the present study was based on previously studies $(9,30,31)$ and our preliminary experiments. The hens had ad libitum access to feed and water, the ambient temperature was maintained at approximately $20-23^{\circ} \mathrm{C}$ with the relative humidity maintained at about $60 \%$, and the photoperiod was $16 \mathrm{~L}$ (light):8 D (dark). During the period of the experiment, the egg laying rate (number of eggs/50 hens) of each treatment group was recorded daily. At the end of the experiment, 30 eggs from each treatment group were randomly collected to assess egg quality parameters. The eggs were weighed and then the eggshell thickness and albumen height were measured with the digital egg tester (DET6000, NABEL Co., Ltd, Kyoto, Japan). For measuring egg protein quality, Haugh 
TABLE 1 | Composition and nutrient level of the basal diets.

\begin{tabular}{lclc}
\hline Ingredients & Content (\%) & Nutrient & Content (per kg diets) \\
\hline Corn & 61.7 & Met & $0.11-0.24 \%$ \\
Soybean meal & 25.0 & Lys & $0.22-0.30 \%$ \\
Limestone & 8.3 & Vitamin mixture & $\geq 58 \mathrm{mg}$ \\
Additive premix & 5 & $\mathrm{Ca}$ & $0.25-1.0 \%$ \\
& $\mathrm{P}$ & $0.09-0.25 \%$ \\
& $\mathrm{Cu}$ & $7-21 \mathrm{mg}$ \\
& $\mathrm{Fe}$ & $80-650 \mathrm{mg}$ \\
& $\mathrm{Mn}$ & $60-150 \mathrm{mg}$ \\
& $\mathrm{Zn}$ & $60-150 \mathrm{mg}$ \\
& $\mathrm{Se}$ & $0.1-0.3 \mathrm{mg}$ \\
& $\mathrm{I}$ & $0.3-0.9 \mathrm{mg}$ \\
& $\mathrm{NaCl}$ & $0.2-0.45 \%$ \\
& $\mathrm{Choline}$ chloride & $0.28 \mathrm{~g}$ \\
\hline
\end{tabular}

units $(\mathrm{HU})$ were calculated by $100 \times \log (($ albumen height $)+$ 7.57-1.7 $\times($ egg weight $) \wedge 0.37)$, which has been accepted for use by the USDA-Agricultural Marketing Service (USDA, 2000).

\section{Sampling}

At the end of the experiment (10:00 at the 14th experimental day), five hens per treatment group were randomly chosen for sampling. Blood of these hens were withdrawn by cardiac puncture to obtain serum sample. After that, hens were killed by cervical bleeding post-anesthesia. Intestinal contents were collected from duodenum, spun down at $3000 \mathrm{~g}$ for $10 \mathrm{~min}$, and then the supernatant of intestinal fluid were aliquoted and frozen at $-20^{\circ} \mathrm{C}$ until analyzing. Then, the duodenum, jejunum and ileum of each hen was collected and cleaned using PBS (phosphate buffer saline, $\mathrm{pH}$ 7.4), then frozen with liquid nitrogen until used for analysis. The blood was placed on $37^{\circ} \mathrm{C}$ for $2 \mathrm{~h}$ then centrifuged at $1000 \times \mathrm{g}$ for $10 \mathrm{~min}$ to obtain serum, and stored at $-70^{\circ} \mathrm{C}$ until use for analysis. This study was carried out in accordance with the Guiding Principles for the Care and Use of Laboratory Animals of Zhejiang University. The experimental protocols were approved by the Committee on the Ethics of Animal Experiments of Zhejiang University (No.: ZJU2015-156-12).

\section{Screening of Laying Property Related Intestinal AA Transporters}

For the identification of which intestinal AA transporter is closely related to laying property, five female Hyline chickens were randomly collected from one of the four stages to analyze mRNA expression of transporters (PepT1, $\mathrm{B}^{0} \mathrm{AT}, \mathrm{b}^{0,+} \mathrm{AT}$, LAT1, $\mathrm{y}^{+} \mathrm{LAT} 2$, CAT1, and EAAT3) in small intestine by RT-PCR. The four stages including just hatching (1 days old), pre-laying period (about 100 days old), laying peak period (about 300 days old) and postlaying period (about 600 days old). These preliminary screening results were further verified in small intestine of hens of the same age (about 300 days old) but with different laying traits (hens with high laying performance (Hens-H), hens with low laying performance (Hens-L) and broilers) by qRT-PCR.

\section{RNA Extraction, RT-PCR, and Quantitative Real-Time PCR}

Trizol reagent (Invitrogen Co., Carlsbad, CA, USA) was used to extract total RNA from small intestine. The cDNA was generated from $2 \mu \mathrm{g}$ of RNA by using the SuperScript First-Strand Synthesis System (Fermantas, Glen Burnie, MD, USA). PCR amplification was performed on a $20 \mu \mathrm{l}$ volume containing $2 \mu \mathrm{l}$ cDNA. For Quantitative Real-time RT-PCR (qRT-PCR), $2 \mu \mathrm{l} c \mathrm{cDNA}$ template, $400 \mathrm{nM}$ primers, $0.4 \mu \mathrm{l}$ ROX reference dye II, and $10 \mu \mathrm{l}$ SYBR Premix Ex Taq (TaKaRa Bio Inc., Shiga, Japan) were mixed gently and reacted as follows: $95^{\circ} \mathrm{C}$ for $10 \mathrm{~s}, 40$ cycles of $95^{\circ} \mathrm{C} 5 \mathrm{~s}$ followed by $60^{\circ} \mathrm{C} 34 \mathrm{~s}$. All samples were repeated in triplicate, and all experiments were performed twice. All samples were normalized with GAPDH using the comparative cycle threshold method $\left(2^{-[\Delta][\Delta] C t}\right)$. The sequences of the primers were listed in Table 2.

\section{Serum AA Analysis}

Serum samples were acid hydrolyzed with $1.0 \mathrm{~mL} 6 \mathrm{~mol} / \mathrm{L}$ $\mathrm{HCl}$ in vacuum-sealed hydrolysis vials at $110^{\circ} \mathrm{C}$ for $22 \mathrm{~h}$. After centrifugation, the supernatant was then diluted with $0.02 \mathrm{~mol} / \mathrm{L}$ hydrochloric acid. After filtering through a Millipore membrane $(0.22 \mu \mathrm{m})$, the content of AA were analyzed using Amino Acid Analyzer (L-8900 Hitachi-hitech, Japan).

\section{Crypt Isolation and Culture}

Isolation and culture of chicken's intestinal crypts was performed base on the protocol previously published (32). Briefly, clean jejunum of 2-week-old Hyline hens were cut into 2-4 $\mathrm{mm}^{3}$ pieces and shaken gently in $2 \mathrm{mM}$ cold EDTA (ethylenediaminetetraacetic acid, $\mathrm{pH}$ 7.4). After passing through a $70-\mu \mathrm{m}$ nylon cell strainer (352360, Corning, NY, USA), the crypts were purifying by centrifugation and re-suspended. Successively, the purified crypts were then mixed with Matrigel (354277, Corning, NY, USA), dropped into 24-well flat-bottom plate, administrated with complete culture medium, and cultured at $38^{\circ} \mathrm{C}$ in a $5 \% \mathrm{CO}_{2}$ atmosphere. All these wells were divided into four groups which were added MEL (M5250, Sigma, St. Louis, MO, USA) at different concentrations $(0,0.25,0.5$, and $1 \mu \mathrm{M}$ ) from the beginning to the fifth day of culture. The dosage of MEL treatment was based on our preliminary experiments. After dissolving Matrigel by Cell Recovery Solution (354253, Corning, NY, USA), the crypts "organoids" were collected and spun down. Then, after discarding supernatant, Trizol reagent were used to extract total RNA by protocol above-mentioned.

\section{Detection of MEL Concentration in Serum and Intestinal Fluid}

High performance liquid chromatography (HPLC) analysis was performed to detect MEL concentrations in serum and intestinal fluid. Briefly, $200 \mu \mathrm{l}$ of serum or intestinal fluid was mixed with $1 \mathrm{ml}$ methanol, shaken for $20 \mathrm{~min}$ and centrifuged at $12000 \times \mathrm{g}$ for $10 \mathrm{~min}$. The supernatants were then evaporated until dry and dissolved in $1 \mathrm{ml}$ ethyl acetate, shaken for $20 \mathrm{~min}$ and centrifuged 
TABLE 2 | Primers for qRT-PCR analysis.

\begin{tabular}{|c|c|c|c|}
\hline Genes & Primer sequences $\left(5^{\prime}-3^{\prime}\right)$ & Accession No. & Product (bp) \\
\hline \multirow[t]{2}{*}{ PepT1 (SLC15A1) } & F: GATCACTGTTGGCATGTTCCT & NM_204365 & 146 \\
\hline & R: CATTCGCATTGCTATCACCTA & & \\
\hline$B^{O} A T$ (SLC6A19) & R: CAAGATGAAGCAGGGGGATA & & \\
\hline$b^{O,+} A T$ (SLC7A9) & F: TATTTCACCGTAATGACTTCAAC & NM_001199133 & 112 \\
\hline LAT1 (SLC7A5) & R: GTGGACAGGGTTGTGAAGTA & & \\
\hline \multirow[t]{2}{*}{$y^{+}$LAT1 (SLC7A7) } & F: CCCTGACAGTCTGAGTTTGAT & XM_418326 & 143 \\
\hline & R: AAAGCCAGTAGTTGAAGCAGT & & \\
\hline \multirow[t]{2}{*}{$y^{+}$LAT2 (SLC7A6) } & F: ACCCAAAGGAGTTCTCATCT & XM_015292302.1 & 115 \\
\hline & R: AGTGGTTCCAAGTTCAGCAT & & \\
\hline \multirow[t]{2}{*}{ EAAT3 (SLC1A1) } & F: AAAATGGGAGACAAAGGACAA & XM_424930 & 159 \\
\hline & R: ACGAAAGATTTCCCAGTCCTC & & \\
\hline \multirow[t]{2}{*}{$G P x-3$} & F: AGGAGTACATCCCCTTCCGA & NM_001163232.2 & 124 \\
\hline & R: TAGGGCCCCAGCTCATTITG & & \\
\hline \multirow[t]{2}{*}{$S O D-1$} & F: GGCAATGTGACTGCAAAGGG & NM_205064.1 & 133 \\
\hline & R: CCCCTCTACCCAGGTCATCA & & \\
\hline \multirow[t]{2}{*}{ PRDX-3 } & F: TGGATAAATACCCCGCGCAA & XM_426543.5 & 126 \\
\hline & R: TCTCAGTGCAATGCCAGGTC & & \\
\hline \multirow[t]{2}{*}{ GAPDH } & F: GATGGGTGTCAACCATGAGAAA & NM_204305.1 & 116 \\
\hline & R: CAATGCCAAAGTTGTCATGGA & & \\
\hline
\end{tabular}

at $12000 \times \mathrm{g}$ for $10 \mathrm{~min}$. The supernatants were re-dissolved in $200 \mu \mathrm{l}$ HPLC mobile phase (acetonitrile: water $=25: 75, \mathrm{v} / \mathrm{v}, \mathrm{pH}$ 5.1). After filtering through a Millipore membrane $(0.22 \mu \mathrm{m})$, the samples $(20 \mu \mathrm{l})$ were injected into a Ultimate $A Q-C_{18}$ column $(5 \mu \mathrm{m}, 4.6 \times 250 \mathrm{~mm})$, and then separated by chromatographic system (LC-20, Shimadzu Corp., Kyoto, Japan) at a flow rate of $1 \mathrm{ml} / \mathrm{min}$. The RF-20A fluorescence detector (Shimadzu Corp., Kyoto, Japan) was set to excitation/emission wavelength of $285 / 345 \mathrm{~nm}$.

\section{Data Analysis}

The data were expressed as the means \pm SEM and analyzed by One-Way ANOVA using SPSS 16.0 (SPSS Inc., Chicago, IL, USA). Statistical differences among different groups were evaluated by LSD (Least Significant Difference) Post Hoc Multiple Comparisons test. The significance level was set at $P<0.05$.

\section{RESULTS}

\section{Effect of MEL on Egg Laying Rate and Egg Quality}

The daily laying rate of $0.625 \mathrm{mg} \mathrm{MEL} / \mathrm{kg}$ diets groups maintains at a higher level throughout the experiment period (Figure 1). Compared with control group, the mean egg laying rate in the
$0.625,2.5$, and $10 \mathrm{mg} \mathrm{MEL} / \mathrm{kg}$ diets groups was increased by $4.3 \%$ ( $P=0.016), 2.4 \%(P=0.163)$, and $2.0 \%(P=0.250)$, respectively during the MEL feeding period (Figure 1). For analysis of the effect of MEL on egg quality, the eggshell thickness, albumen height, and HU of the eggs were assayed. The results (Figure 1) showed that eggshell thicknesses of the $0.625,2.5$, and $10 \mathrm{mg}$ $\mathrm{MEL} / \mathrm{kg}$ diets groups were higher than those of the control group by $16.9 \%(P<0.01), 1.5 \%(P=0.465)$, and $6.8 \%(P<0.01)$, respectively. Simultaneously, albumen heights for the $0.625,2.5$, and $10 \mathrm{mg} \mathrm{MEL} / \mathrm{kg}$ diets groups were higher at the ratios of $4.5 \%$ $(P=0.042), 3.4 \%(P=0.110)$, and $3.3 \%(P=0.111)$ of those of control group, respectively. However, the $\mathrm{HU}$ of eggs of the $0.625,2.5$, and $10 \mathrm{mg} \mathrm{MEL} / \mathrm{kg}$ diets groups were higher only by $0.1-1.8 \%$ and without statistical difference.

\section{Effect of MEL on Serum AA Levels}

After feeding MEL to laying hens for 2 weeks, the hens serums AA were measured. As shown in Table 3, compared with control group, the 0.625 and $2.5 \mathrm{mg} \mathrm{MEL} / \mathrm{kg}$ diets groups presented statistically significant higher Asp (by 220.4-233.3\%, $P<0.01$ ), Thr (by $80.0-118.3 \%, P<0.01$ ), Ser (by $90.1-111.3 \%, P<0.01$ ), Glu (242.8-274.2\%, $P<0.01$ ), Gly (by 363.2-368.4\%, $P<0.01$ ), Ala (by 292.9-308.9\%, $P<0.01$ ), Ile (116.6-116.7, $P<0.01$ ), Leu (by 198.9-225.5\%, $P<0.01$ ), Tyr (by 98.2-105.4\%, $P<0.01$ ), Phe (by 209.9-215.5\%, $P<0.01$ ), Lys (by $217.8-242.5 \%, P<0.01$ ), 

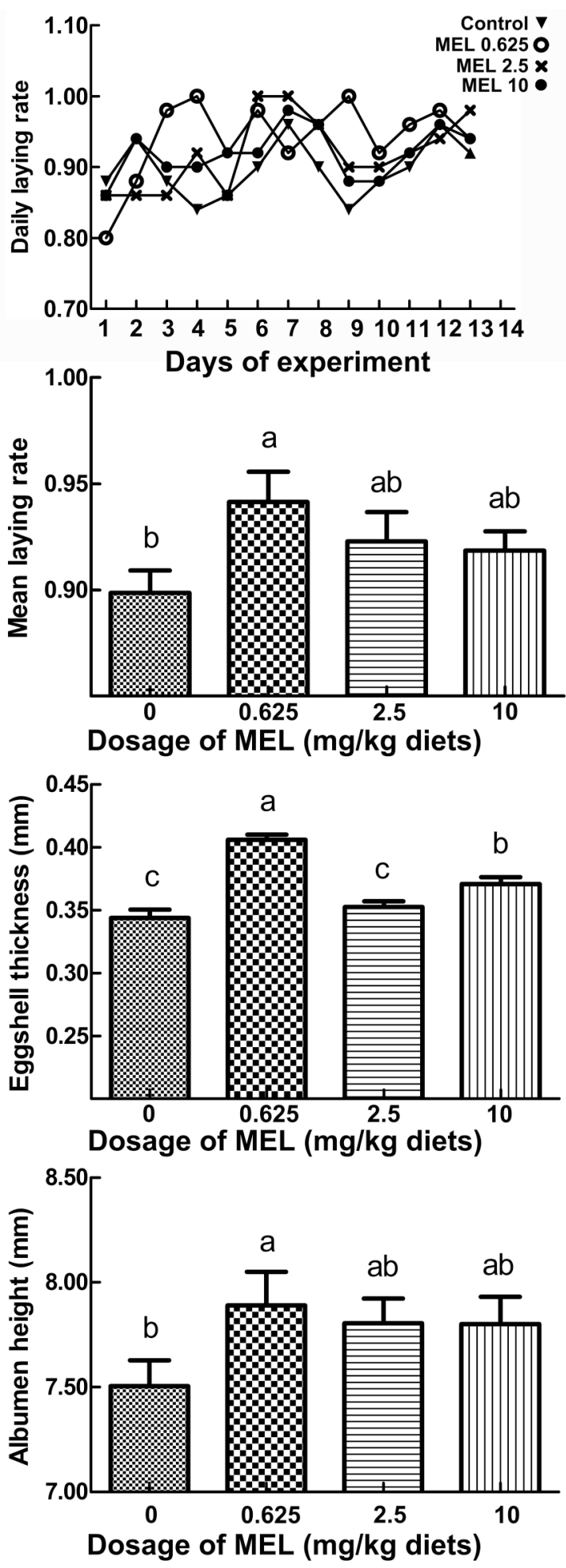

FIGURE 1 | The effect of MEL feeding on laying performance and egg quality Laying hens were fed daily with diets containing 0, 0.625, 2.5, and $10 \mathrm{mg}$ MEL/kg, respectively, for 2 weeks. Thereafter, laying performance and egg quality were analyzed. The daily laying rate of each group was calculated as "number of eggs/50 hens." The mean laying rate of each group was the average of the daily laying rate during the experimental period. Values with no common letters are significantly different $(P<0.05)$.
TABLE 3 | Effect of MEL feeding on serum AA levels in laying hens $(n=5)$.

\begin{tabular}{|c|c|c|c|c|c|c|c|c|}
\hline \multirow{3}{*}{$\begin{array}{l}\text { AA } \\
\text { (g/100g } \\
\text { protein) }\end{array}$} & \multicolumn{2}{|c|}{ Control } & \multicolumn{6}{|c|}{ Melatonin feeding (mg/kg diets) } \\
\hline & & & \multicolumn{2}{|c|}{0.625} & \multicolumn{2}{|c|}{2.5} & \multicolumn{2}{|c|}{10} \\
\hline & Mean & SEM & Mean & SEM & Mean & SEM & Mean & SEM \\
\hline Asp & 0.93 & $0.04^{b}$ & 3.10 & $0.18^{a}$ & 2.98 & $0.18^{a}$ & 1.47 & $0.13^{b}$ \\
\hline Thr & 0.60 & $0.02^{b}$ & 1.31 & $0.18^{a}$ & 1.08 & $0.09^{a}$ & 1.03 & $0.05^{a b}$ \\
\hline Ser & 0.71 & $0.04^{b}$ & 1.50 & $0.11^{\mathrm{a}}$ & 1.35 & $0.06^{a}$ & 1.34 & $0.09^{a}$ \\
\hline Glu & 1.24 & $0.04^{b}$ & 4.64 & $0.26^{a}$ & 4.25 & $0.41^{a}$ & 3.60 & $0.07^{a}$ \\
\hline Gly & 0.38 & $0.02^{b}$ & 1.76 & $0.12^{a}$ & 1.78 & $0.11^{a}$ & 0.68 & $0.19^{b}$ \\
\hline Ala & 0.56 & $0.04^{b}$ & 2.20 & $0.56^{a}$ & 2.29 & $0.42^{a}$ & 1.27 & $0.05^{a b}$ \\
\hline Cys & 0.16 & $0.01^{b}$ & 0.14 & $0.01^{b}$ & 0.17 & $0.06^{b}$ & 0.36 & $0.03^{a}$ \\
\hline Val & 0.82 & $0.05^{b}$ & 1.40 & $0.22^{a b}$ & 1.48 & $0.14^{a}$ & 1.14 & $0.10^{a b}$ \\
\hline Met & 0.37 & 0.07 & 0.46 & 0.06 & 0.71 & 0.11 & 0.67 & 0.11 \\
\hline Ile & 0.72 & $0.17^{b}$ & 1.56 & $0.10^{a}$ & 1.56 & $0.17^{a}$ & 1.00 & $0.07^{a b}$ \\
\hline Leu & 0.94 & $0.10^{C}$ & 3.06 & $0.13^{a}$ & 2.81 & $0.32^{a b}$ & 2.03 & $0.04^{b}$ \\
\hline Tyr & 0.56 & $0.01^{b}$ & 1.11 & $0.06^{a}$ & 1.15 & $0.05^{a}$ & 1.06 & $0.10^{\mathrm{a}}$ \\
\hline Phe & 0.71 & $0.01^{c}$ & 2.24 & $0.07^{a}$ & 2.20 & $0.06^{a}$ & 1.04 & $0.05^{b}$ \\
\hline Lys & 0.73 & $0.07^{b}$ & 2.50 & $0.09^{a}$ & 2.32 & $0.27^{a}$ & 1.24 & $0.16^{b}$ \\
\hline His & 0.26 & $0.01^{c}$ & 1.23 & $0.03^{a}$ & 1.25 & $0.06^{a}$ & 0.75 & $0.06^{b}$ \\
\hline Arg & 0.67 & $0.06^{b}$ & 1.82 & $0.14^{a}$ & 1.89 & $0.14^{a}$ & 0.90 & $0.09^{b}$ \\
\hline Pro & 0.44 & $0.03^{b}$ & 1.82 & $0.10^{a}$ & 1.88 & $0.16^{a}$ & 0.53 & $0.03^{b}$ \\
\hline
\end{tabular}

${ }^{a-d}$ Values with no common letters are significantly different $(P<0.05)$ within one $A A$.

His (by $373.1-380.7 \%, P<0.01$ ), Arg (by $171.6-182.1 \%$, $P<0.01$ ), and Pro (by 313.6-327.3\%, $P<0.01$ ). In addition, the $10 \mathrm{mg} \mathrm{MEL} / \mathrm{kg}$ diets group presented higher Ser (by $88.7 \%$, $P<0.01$ ), Glu (190.3\%, $P<0.01$ ), Cys (by $125.0 \%, P<0.01$ ), Leu (116.0\%, $P<0.01$ ), Tyr (by $89.3 \%, P<0.01$ ), Phe (by $46.5 \%$, $P<0.01)$, and His $(188.5 \%, P<0.01)$ than those of the control group.

\section{Screening of Intestinal AA Transporters Which Is Related to Laying Property}

The RT-PCR screening results (Figure 2) showed that, in the duodenum, PepT1, $B^{0} A T, b^{0,+} A T, L A T 1$, and EAAT3 were more highly expressed in laying peak period than in the post-laying period, especially for PepT1 which was at an ever higher level than that of the pre-laying period (arrows, Figure 2B). In the jejunum, PepT1, $B^{0} A T, b^{0,+} A T, L A T 1, y^{+} L A T 2, C A T 1$, and EAAT3 levels were higher in laying peak period than in the post-laying period. Among them, PepT1, $B^{0} A T, b^{0,+} A T, L A T 1, y^{+} L A T 2, C A T 1$, and $E A A T 3$ were even higher than that in the pre-laying period (arrows, Figure 2B). In the ileum, all the transporters detected were higher in the laying peak period than in the post-laying period, moreover, PepT1 levels were higher than in the pre-laying period (arrows, Figure 2B).

The qRT-PCR verification (Figure 3) in the small intestine of hens with different productive traits (hens- $\mathrm{H}$, hens- $\mathrm{L}$ and broilers) showed that throughout the small intestine (duodenum, jejunum and ileum), hens- $\mathrm{H}$ presented dramatically higher PepT1 (281.6-3924.0\% higher than hens-L and 961.7-6312.6\% higher than broilers), higher $B^{0} A T$ (479.3-1597.9\% higher than 


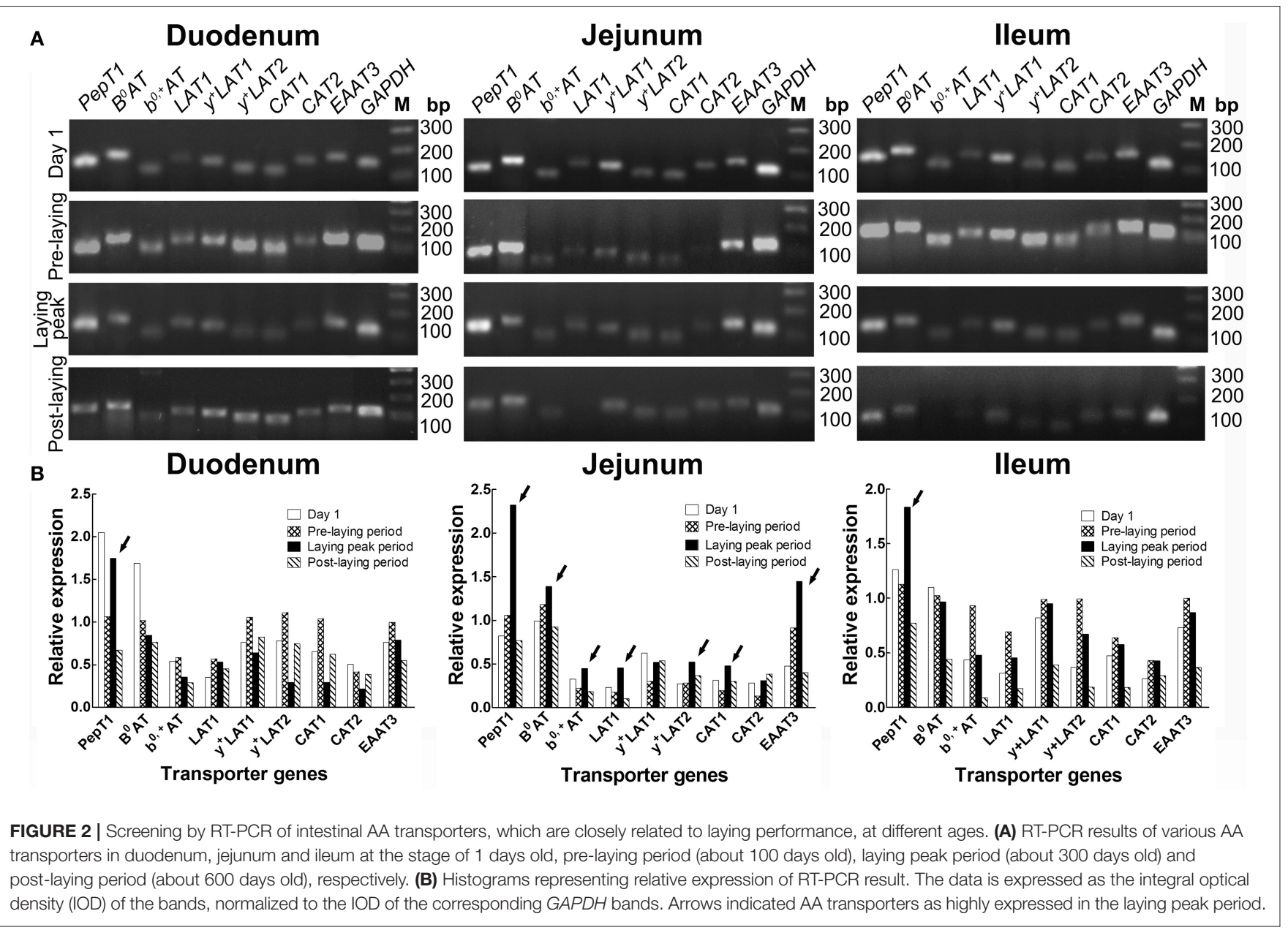

hens-L and 253.7-1221.6\% higher than broilers), higher $b^{0,+} A T$ (1801.6-2097.1\% higher than hens-L and 156.9-3363.9\% higher than broilers), and higher EAAT3 (861.2-2414.3\% higher than hens-L and 452.2-1977.1\% higher than broilers).

\section{Effect of MEL on Transporter mRNA Expression in Small Intestine of Laying Hens}

In the peak laying period and after MEL $(0.625,2.5$, and 10 $\mathrm{mg} / \mathrm{kg}$ diets) feeding for 2 weeks, PepT1, $B^{0} A T, b^{0,+} A T$, and EAAT3 expressions in small intestine were analyzed. The results (Figure 4) showed that, compared with control group, $0.625 \mathrm{mg}$ $\mathrm{MEL} / \mathrm{kg}$ diets promoted the expression of PepT1 (by $374.3 \%$, $P<0.01$ ), $B^{0} A T$ (by $182.5 \%, P<0.01$ ), $b^{0,+} A T$ (by $569.7 \%$, $P<0.01$ ), and EAAT3 (by $293.9 \%, P<0.01$ ) in the duodenum, promoted the expression of PepT1 (by $3949.9 \%, P<0.01$ ), $B^{0} A T$ (by $6045.9 \%, P<0.01$ ),$b^{0,+} A T$ (by $603.5 \%, P<0.01$ ), and EAAT3 (by $412.7 \%, P<0.01$ ) in the jejunum, and promoted the expression of PepT1 (by 58.7\%, $P=0.018$ ) in the ileum. Moreover, $2.5 \mathrm{mg} \mathrm{MEL} / \mathrm{kg}$ diets increased the expression of $b^{0,+} A T$ (by $174.5 \%, P<0.01$ ) in the duodenum and EAAT3 (by $33.1 \%, P<0.01)$ in the jejunum. Furthermore, $10 \mathrm{mg} \mathrm{MEL} / \mathrm{kg}$ diets treatment elevated the expression of $B^{0} A T$ (by $751.9 \%$, $P<0.01$ ) and $P e p T 1$ (by $601.7 \%, P<0.01$ ) in the jejunum.

\section{Effect of MEL on Transporter Transcription in Cultured Crypt "Organoids"}

Intestinal stem cells in the crypt can differentiate into various types of epithelial cells, including enterocytes. Hence, in vitro cultured crypt "organoids" can be used for the analysis of the effect of MEL on the transcription of intestinal AA transporters. In the present study, we added $\operatorname{MEL}(0.25,0.5$, and $1 \mu \mathrm{M})$ to the chicken's intestinal crypt "organoids" for 5 days (Figure 5A) where qRT-PCR were then used to detect the expression of PepT1, $B^{0} A T, b^{0,+} A T$, and EAAT3. The results (Figure 5B) showed that, compared with $0 \mu \mathrm{M}$ MEL group, $0.5 \mu \mathrm{M}$ MEL treatment enhanced the expression of PepT1 and EAAT3 by $35.4 \%(P=0.028)$ and $160.1 \%(P=0.021)$ respectively. However, $b^{0,+} A T$ at $0.5 \mu \mathrm{M}$ MEL treatment group was higher than control group by $110.0 \%$, but without statistical significance $(P=0.203)$.

\section{MEL Concentrations in Serum and Intestinal Fluid}

For analyzing the acting pathway of MEL, $1 \mathrm{~h}$ after MEL feeding at the 14th day of experiment period, concentrations of MEL in 


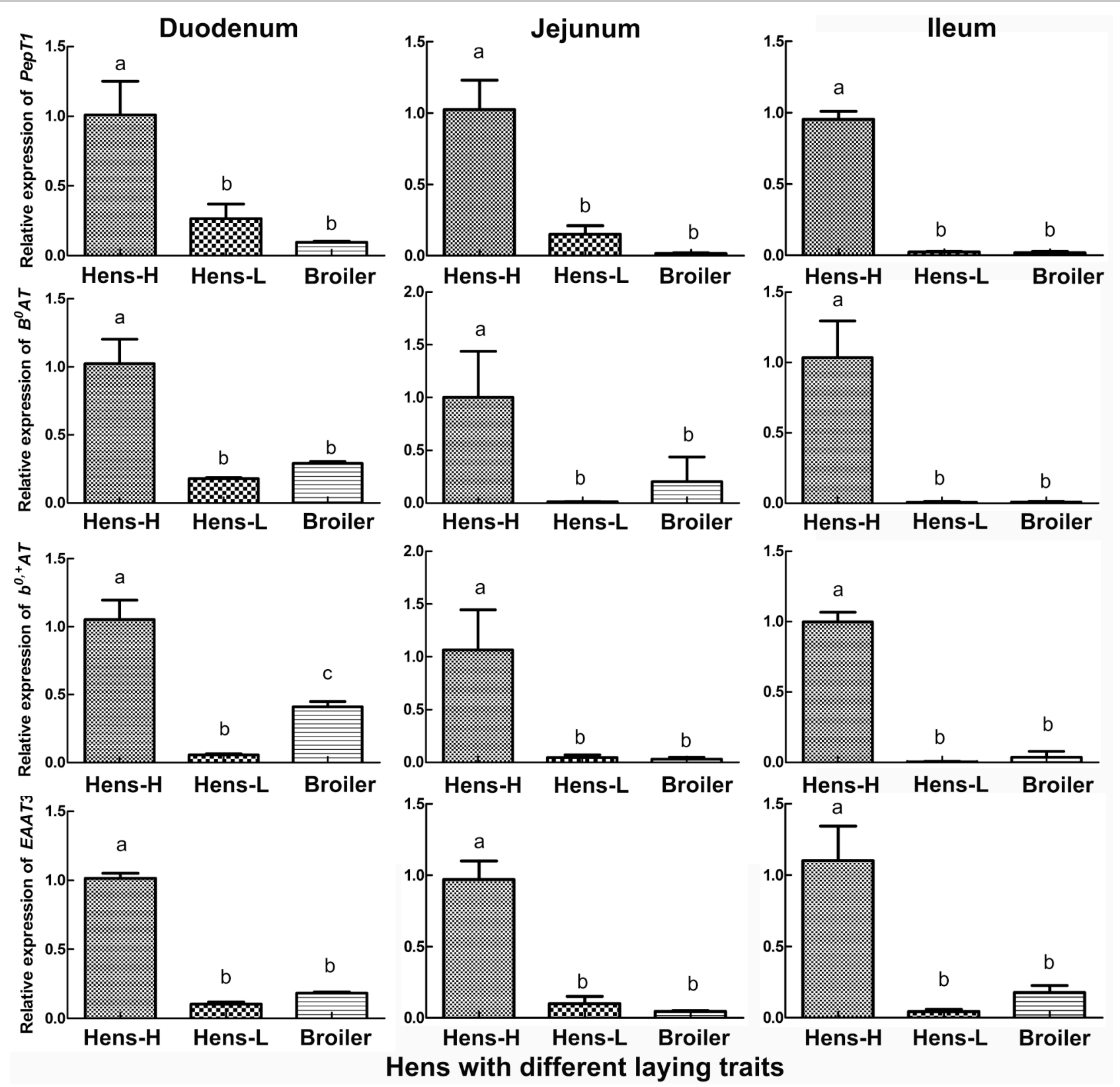

FIGURE 3 | Screening by qRT-PCR of intestinal AA transporters, which are closely related to laying performance, among hens with different productive traits. Hens-H, hens with high laying performance. Hens-L, hens with low laying performance. Values with no common letters are significantly different $(P<0.05)$.

serum and intestinal fluid were determined by HPLC. As shown in Figure 6, in serum, MEL concentration in $10 \mathrm{mg} / \mathrm{kg}$ diets group $(588.5 \mathrm{pg} / \mathrm{ml})$ was significantly higher than the control group (360.1 pg/ml), $0.625 \mathrm{mg} / \mathrm{kg}$ diets group $(365.5 \mathrm{pg} / \mathrm{ml})$ and $2.5 \mathrm{mg} / \mathrm{kg}$ diets group $(433.3 \mathrm{pg} / \mathrm{ml})$. However, there has no significant difference amount other groups. Meanwhile, intestinal fluid showed an increase in MEL concentration with increasing MEL dosage in the diets. After MEL feeding, much higher MEL concentrations were observed in the intestinal fluid than that of the control group.

\section{Effect of MEL on Antioxidase Gene} Transcription in Crypt "Organoids" and the Small Intestine

To further validate the possible pathway of MEL promotion on laying properties, the expression of the antioxidase genes GPX3, SOD-1, and PRDX-3 were analyzed. In the crypt "organoids" (Figure 5B), GPx-3 was higher in $0.5 \mu \mathrm{M}$ MEL treatment group than control group by $20.2 \%(P=0.076)$. In the aspect of in vivo study, compared with control group, nearly all the MEL dosages could enhance GPX-3, SOD-1, and PRDX-3 expression 


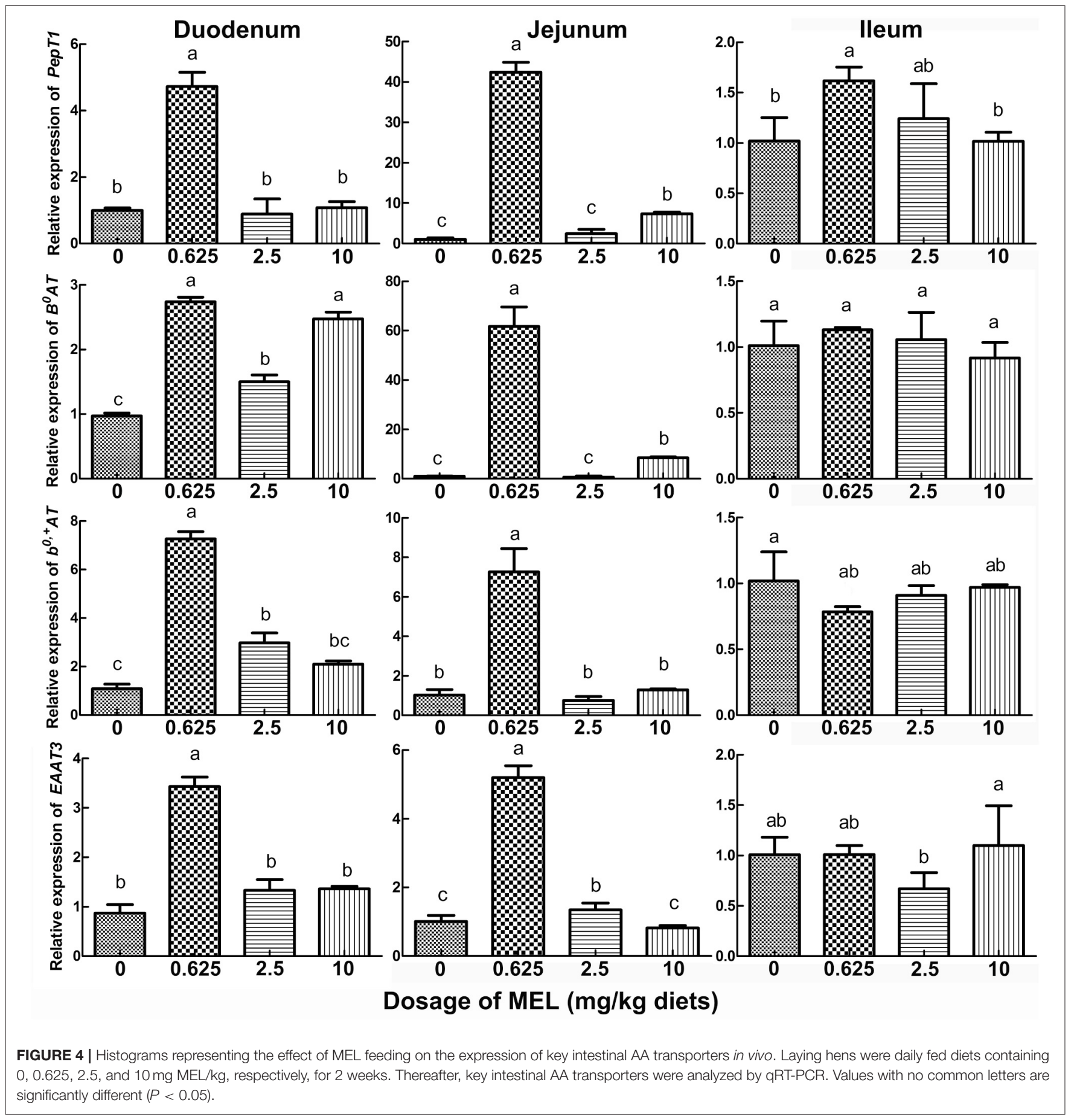

in the duodenum (Figure 7), especially for $0.625 \mathrm{mg} \mathrm{MEL} / \mathrm{kg}$ diets group which presented an even higher GPx-3 (by $45.9 \%$, $P<0.01$ ), SOD-1 (by 205.4\%, $P<0.01$ ), and $P R D X-3$ (by $184.3 \%$, $P<0.01)$. In the jejunum, the $0.625 \mathrm{mg} \mathrm{MEL} / \mathrm{kg}$ diets remarkably promoted the expression of GPx-3, SOD-1, and PRDX-3 by 579.2\% $(P<0.01), 517.9 \%(P<0.01)$ and $8130.0 \%(P<0.01)$ respectively, when compared with control group. However, the antioxidant function of MEL in the ileum remained mild where GPx-3 had only showed an increased in the $2.5 \mathrm{mg} \mathrm{MEL} / \mathrm{kg}$ diets group (by $29.0 \%, P<0.01$ ), and only $P R D X-3$ showed an increase in the $10 \mathrm{mg} \mathrm{MEL} / \mathrm{kg}$ diets group (by 33.8\%, $P<0.01$ ), when compared with control group. 


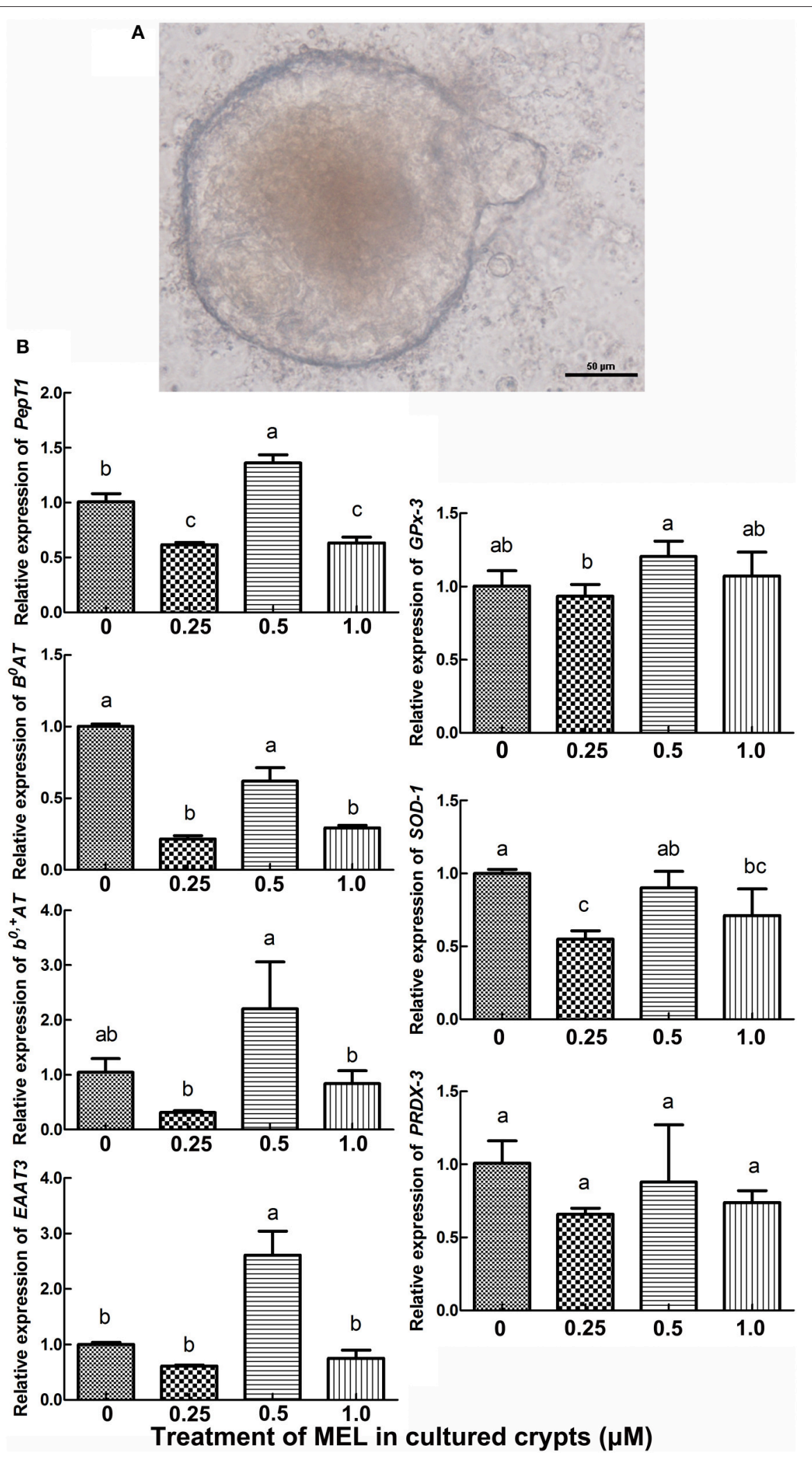

FIGURE 5 | Histograms representing effect of MEL treatment on key intestinal AA transporters and antioxidase mRNA expression in vitro. (A) in vitro cultured chicken crypt "organoids" which were treated with MEL at the concentrations of 0, 0.25, 0.5, and $1 \mu \mathrm{M}$ for 5 days. Scale bar: $50 \mu \mathrm{m}$. (B) qRT-PCR result of various AA transporters and antioxidase's mRNA expression in crypt "organoids" after MEL treatment. Values with no common letters are significantly different $(P<0.05)$. 


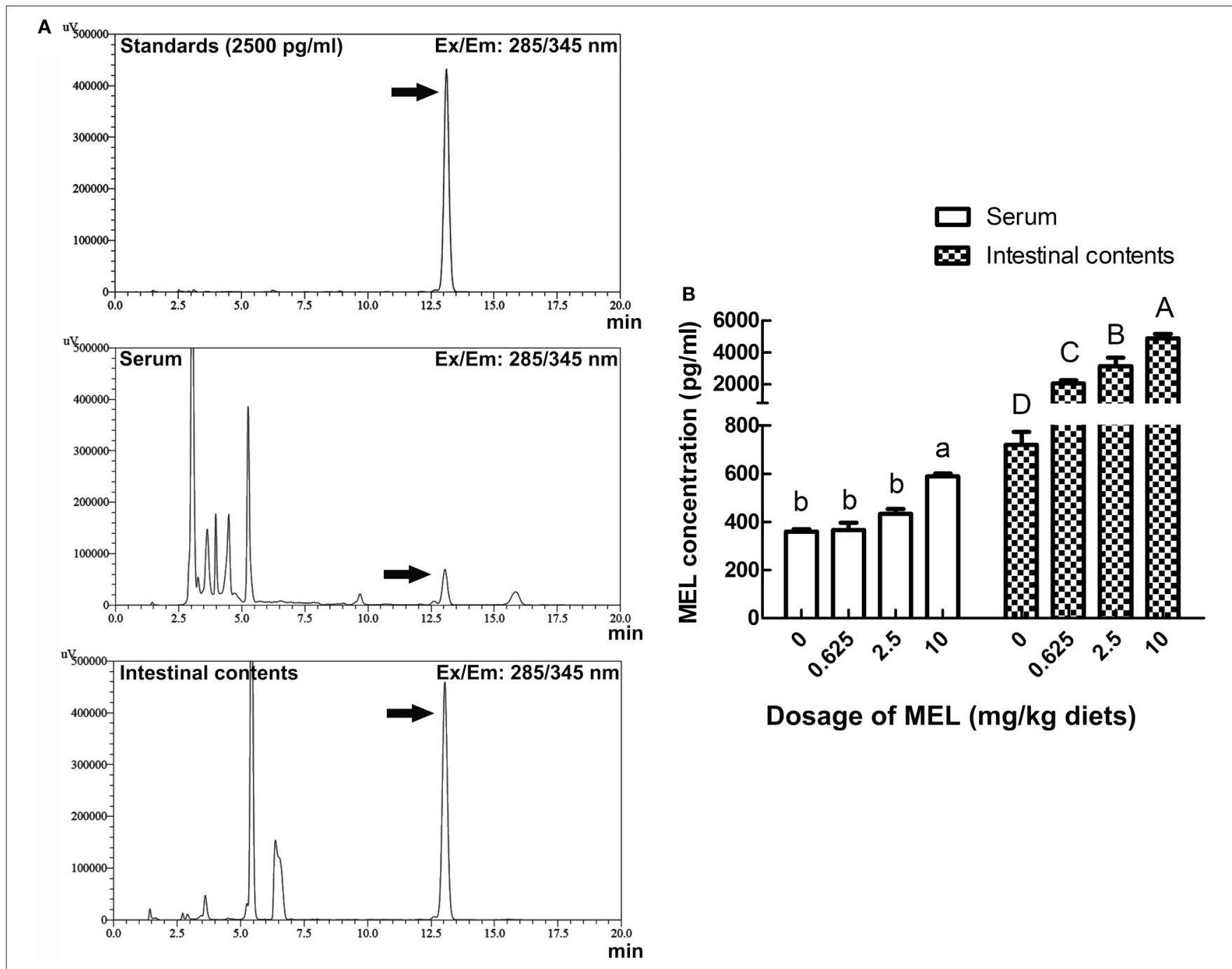

FIGURE 6 | Effects of MEL feeding on MEL concentrations in serum and intestinal fluid by HPLC. (A) HPLC result of 2500 pg/ml MEL standards, serum, and intestinal contents. (B) Statistical result of MEL concentrations in serum and intestinal fluid of laying hens after MEL feeding. Values with no common letters are significantly different $(P<0.05)$.

\section{DISCUSSION}

In this study, feeding the $0.625 \mathrm{mg} \mathrm{MEL} / \mathrm{kg}$ diets could significantly increase egg laying rate. Similarly, feeding of $0.03-3$ $\mathrm{mg} / \mathrm{kg}$ MEL diets could considerably improve egg weight in laying hens (9). MEL implanted into 470 days old hens could increase the egg-laying rate and reduce the frequency of the occurrence of sharpei eggs (10). Eggshell and albumen quality are important fundamental economic indexes for the egg industry. Here, eggshell thickness and albumen height could be increased by feeding the $0.625 \mathrm{mg} \mathrm{MEL} / \mathrm{kg}$ diets. In addition, eggshell thickness could also be increased by dietary xylanase (33). Numerous studies have shown that egg albumen height could be increased by dietary supplements such as xylanase (33), vitamins C (34) or tea polyphenols (35). Conversely, increased plasma MEL can elevate hypothalamic gonadotropin-inhibitory hormone (GnIH) mRNA expression in chicken (36) and quail (37). Increased GnIH release acts to inhibit plasma luteinizing hormone (LH) concentrations, which will then repress ovarian function. In the present study, $1 \mathrm{~h}$ after MEL feeding, serum MEL level of lower dosage feeding group $(0.625$ and $2.5 \mathrm{mg} / \mathrm{kg}$ diets) were comparable to that of control group and significantly lower than higher dosage feeding group $(10 \mathrm{mg} / \mathrm{kg}$ diets). These results align well with our finding that a lower dosage of MEL supplement could improve laying performance and egg quality, but that higher dosage of MEL supplementation may suppress the physiological function of the ovary, and subsequently compromise the beneficial effect of MEL on laying property.

For demonstrating whether the improvement of MEL on laying property and egg quality was mediated by intestinal AA transport, we screened the AA transporters which are 


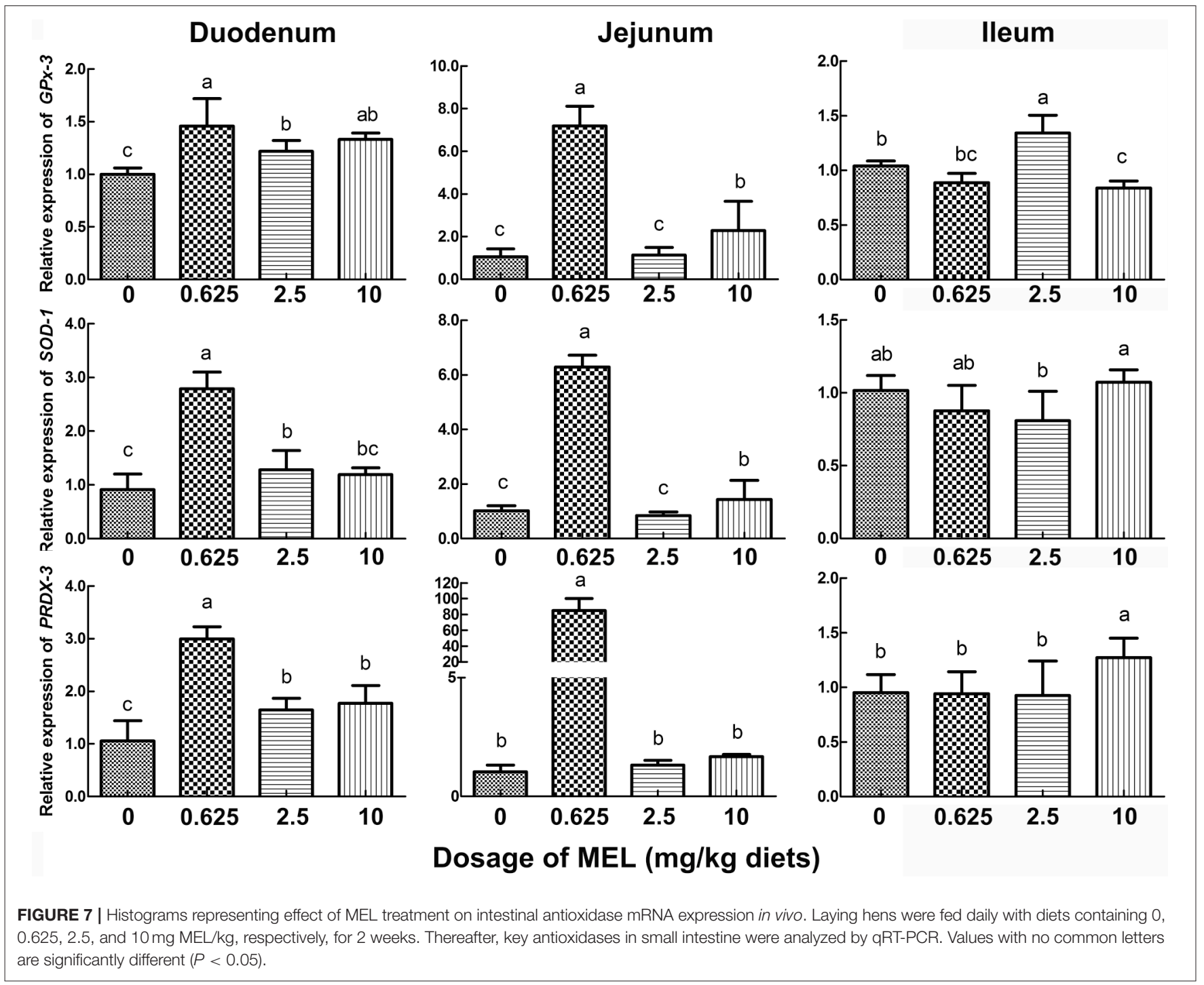

closely related to laying performance. Compared with pre-laying or post-laying period, PepT1, $B^{0} A T, b^{0,+} A T, L A T 1, y^{+} L A T 2$, $C A T 1$, and EAAT3 were highly expressed in the jejunum of hens in laying peak period. Moreover, $P e p T 1, B^{0} A T, b^{0,+} A T$, and EAAT3 in small intestine of hens- $\mathrm{H}$ were notably higher than hens-L and broilers. In as much as most AA absorption takes place in the jejunum (38), our result indicated that PepT1, $\mathrm{B}^{0} \mathrm{AT}, \mathrm{b}^{0,+} \mathrm{AT}$, and EAAT3 in the jejunum was closely related to laying performance. Interestingly, after MEL treatment, PepT1, $B^{0} A T, b^{0,+} A T$, and EAAT3 mRNA expression in the duodenum and jejunum of laying hens were also substantially elevated, and PepT1 and EAAT3 levels in the intestinal crypt "organoids" were also considerably increased. Consistently, MEL i.p. provision could promote intestinal $B^{0} A T$ and EAAT3 mRNAs expression in young chickens (7), where the transcription of the $B^{0} A T$ gene in the enterocytes is regulated at three different levels involving promoter methylation, histone modification, and opposing transcription factors (39). Similarly, PepT1 expression in the rat duodenum could be enhanced by zinc glycine chelate supplementation (40). These results indicated that $P e p T 1, B^{0} A T$, $b^{0,+} A T$, and EAAT3 expression in the small intestine of laying hens could be up-regulated by MEL.

Egg laying performance can be influenced by AA absorption. Azzam et al. (2011) demonstrated that $0.2 \%$ LThr supplementation resulted in optimal egg production (12). Adequate dietary Lys and Ile should be provided for maximum hatching egg production (13). The Arg-silicate-inositol complex supplementation in laying hens during the peak laying period improved eggshell quality through improving calcium utilization (14). In addition to Thr, Lys and Arg which have shown above, a lower dosage of MEL ( 0.625 or $2.5 \mathrm{mg} / \mathrm{kg}$ diets) in the present study could dramatically elevate serum Asp, Thr, Ser, Glu, Gly, Ala, Ile, Leu, Tyr, Phe, Lys, His, Arg, and Pro levels in laying hens. These results are almost completely in accordance with the function of MEL-enhanced intestinal $P e p T 1, B^{0} A T$, $b^{0,+} A T$, and EAAT3. Similarly, intestinal $B^{0} A T$ and EAAT3 
mRNAs expression in young chicken could be elevated by MEL (1-10 $\mu \mathrm{g} / \mathrm{d})$ injection (7). MEL $(0.2 \mathrm{mg} / \mathrm{mL})$ could also restore DSS-induced decrease of Glu and Cys in mice serum (15). These results indicate that lower dosage of MEL feeding in laying hens could increase the AA levels in serum by enhancing transcription of $P e p T 1, B^{0} A T, b^{0,+} A T$, and EAAT3 mRNA in the small intestine.

A previous study demonstrated that the physiological dose of MEL in the chicken was between $100 \mathrm{pg} / \mathrm{ml}$ and $10 \mathrm{ng} / \mathrm{ml}$ (41). In this study, serum MEL concentration in laying hens was about $300-400 \mathrm{pg} / \mathrm{ml}$ at midday, and feeding lower MEL dosage ( 0.625 and $2.5 \mathrm{mg} / \mathrm{kg}$ diets) did not increase serum MEL level significantly. However, MEL concentration in the intestinal fluid increased with increasing MEL dosage in diets. These results suggested that the effects of MEL feeding were mainly exerted by acting locally on intestine instead of increasing circulating MEL levels. In the rat, exogenous MEL treatment $(1-1000 \mathrm{mg} / \mathrm{kg}$, i.p.) may act at MEL receptors at lower doses ( 1 or $10 \mathrm{mg} / \mathrm{kg}$ ) to increase intestinal motor activity (42). Under the treatment of MEL $\left(10^{-3}-10^{-9} \mathrm{M}\right)$ in vitro, the ewes' embryos developed well under the lower MEL concentration $\left(10^{-9} \mathrm{M}\right)$, while the highest MEL concentration decreased their viability by reducing ATP concentration (43). These results suggested that lower dosage of MEL feeding in our study was much advantageous to intestinal physiological function. Many studies have shown that lipid peroxidation (26) or oxidative injury (27) can decrease AA transportation in the enterocytes. We demonstrated that MEL feeding could significantly promote $G P x-3, S O D-1$, and $P R D X-3$ expression in the duodenum and jejunum of laying hens. In vitro,

\section{REFERENCES}

1. Bubenik GA. Thirty four years since the discovery of gastrointestinal melatonin. J Physiol Pharmacol. (2008) 59(Suppl. 2):33-51.

2. Bubenik GA, Brown GM. Pinealectomy reduces melatonin levels in the serum but not in the gastrointestinal tract of rats. Biol Signals (1997) 6:40-44. doi: 10.1159/000109107

3. Huether G, Poeggeler G, Reimer R, George A. Effect of tryptophan administration on circulating melatonin levels in chicks and rats: evidence for stimulation of melatonin synthesis and release in gastrointestinal tract. Life Sci. (1992) 51:945-53. doi: 10.1016/0024-3205(92)90402-B

4. Bubenik GA, Pang SF, Cockshut JR, Smith PS, Grovum LW, Friendship $\mathrm{RM}$, et al. Circadian variation of portal, arterial and venous blood levels of melatonin in pigs and its relationship to food intake and sleep. J Pineal Res. (2000) 28:9-15. doi: 10.1034/j.1600-079x.2000.280102.x

5. Bubenik GA. Localization, physiological significance and possible clinical implication of gastrointestinal melatonin. Biol Signals Recept. (2001) 10:35066. doi: 10.1159/000046903

6. Li RX, Li J, Zhang SY, Mi YL, Zhang CQ. Attenuating effect of melatonin on lipopolysaccharide-induced chicken small intestine inflammation. Poult Sci. (2018) 97:2295-302. doi: 10.3382/ps/pey084

7. Li J, Li RX, Liu G, Lv CF, Mi YL, Zhang CQ. Effect of melatonin on renewal of chicken small intestinal mucosa. Poult Sci. (2017) 96:2942-9. doi: $10.3382 / \mathrm{ps} /$ pex085

8. Sommansson A, Yamskova O, Schiöth HB, Nylander O, Sjöblom M. Longterm oral melatonin administration reduces ethanol-induced increases in duodenal mucosal permeability and motility in rats. Acta Physiol. (2014) 212:152-65. doi: 10.1111/apha.12339
$0.5 \mu \mathrm{M}$ MEL could also considerably enhance GPx-3 expression in crypt "organoids." These indicated that the promotion of PepT1, $B^{0} A T, b^{0,+} A T$, and EAAT3 expression and function by MEL may be mediated by this improved antioxidant status.

In conclusion, this study revealed that lower dosage $(0.625 \mathrm{mg}$ $/ \mathrm{kg}$ diets) of MEL feeding in laying hens could act locally on intestine, enhance the intestinal antioxidase gene expression, which further promotes the expression of intestinal $P e p T 1, B^{0} A T$, $b^{0,+} A T$, and EAAT3 and corresponding AA transportation, and result in improved egg laying performance.

\section{AUTHOR CONTRIBUTIONS}

LL, SZ, CC, QY, QZ, CZ, and JL conceived the experiment(s). LL, SZ, JB, XH, DT, CC, QZ, and JL conducted the experiments; all authors joined the analysis and interpretation of data. LL and JL prepared the manuscript. All authors reviewed the manuscript.

\section{ACKNOWLEDGMENTS}

This study was supported by the National Natural Science Foundation of China (No. 31502023) and the Fundamental Research Funds for the Central Universities (No. 2018FZA6017). We are grateful to Yuling Mi (Zhejiang University), Weidong Zeng (Zhejiang University) and The Experimental Teaching Center (College of Animal Sciences, Zhejiang University) for help in the experiments, and Dr. Chris Wood (Zhejiang University) for English improvement in the manuscript.

9. Taylor AC, Horvat-Gordon M, Moore A, Bartell PA. The effects of melatonin on the physical properties of bones and egg shells in the laying hen. PLOS ONE (2013) 8:e55663. doi: 10.1371/journal.pone.0055663

10. Jia Y, Yang M, Zhu K, Wang L, Song Y, Wang J, et al. Melatonin implantation improved the egg-laying rate and quality in hens past their peak egg-laying age. Sci Rep. (2016) 6:39799. doi: 10.1038/srep39799

11. Fisher H, Johnson D Jr. The amino acid requirement of the laying hen. II. Classification of the essential amino acids required for egg production. J Nutr. (1956) 60:275-82.

12. Azzam MM, Dong XY, Xie P, Wang C, Zou XT. The effect of

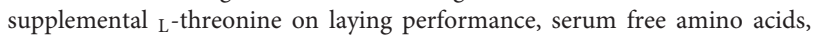
and immune function of laying hens under high-temperature and highhumidity environmental climates. J Appl Poult Res. (2011) 20:361-70. doi: 10.3382/japr.2010-00308

13. Ekmay RD, De Beer M, Mei SJ, Manangi M, Coon CN. Amino acid requirements of broiler breeders at peak production for egg mass, body weight, and fertility. Poult Sci. (2013) 92:992-1006. doi: $10.3382 /$ ps.2012-02554

14. Sahin K, Orhan C, Tuzcu M, Hayirli A, Komorowski JR, Sahin N. Effects of dietary supplementation of arginine-silicate-inositol complex on absorption and metabolism of calcium of laying hens. PLoS ONE (2018) 13:e0189329. doi: 10.1371/journal.pone.0189329

15. Liu G, Jiang Q, Chen S, Fang J, Ren W, Yin J, et al. Melatonin alters amino acid metabolism and inflammatory responses in colitis mice. Amino Acids (2017) 49:2065-71. doi: 10.1007/s00726-017-2489-z

16. Sanderink GJ, Artur Y, Siest G. Human aminopeptidases: a review of the literature. J Clin Chem Clin Biochem. (1988) 26:795-807. doi: $10.1515 / \mathrm{cclm} .1988 .26 .12 .795$ 
17. Daniel H. Molecular and integrative physiology of intestinal peptide transport. Annu Rev Physiol. (2004) 66:361-84. doi: 10.1146/annurev.physiol.66.032102.144149

18. Bröer A, Klingel K, Kowalczuk S, Rasko JE, Cavanaugh J, Bröer S. Molecular cloning of mouse amino acid transport system $\mathrm{B}^{0}$, a neutral amino acid transporter related to Hartnup disorder. J Biol Chem. (2004) 279:24467-76. doi: 10.1074/jbc.M400904200

19. Hundal HS, Taylor PM. Amino acid transceptors: gate keepers of nutrient exchange and regulators of nutrient signaling. Am J Physiol Endocrinol Metab. (2009) 296:E603-13. doi: 10.1152/ajpendo.91002.2008

20. Devés R, Boyd CA. Transporters for cationic amino acids in animal cells: discovery, structure, and function. Physiol Rev. (1998) 78:487-545.

21. Speier JS, Yadgary L, Uni Z, Wong EA. Gene expression of nutrient transporters and digestive enzymes in the yolk sac membrane and small intestine of the developing embryonic chick. Poult Sci. (2012) 91:1941-9. doi: 10.3382/ps.2011-02092

22. Gilbert ER, Li H, Emmerson DA, Webb KE Jr., Wong EA. Developmental regulation of nutrient transporter and enzyme mRNA abundance in the small intestine of broilers. Poult Sci. (2007) 86:1739-53. doi: 10.1093/ps/86. 8.1739

23. Li H, Gilbert ER, Zhang Y, Crasta O, Emmerson D, Webb KE Jr, et al. Expression profiling of the solute carrier gene family in chicken intestine from the late embryonic to early post-hatch stages. Anim Genet. (2008) 39:407-24. doi: 10.1111/j.1365-2052.2008.01744.x

24. Miska KB, Fetterer RH, Wong EA. The mRNA expression of amino acid transporters, aminopeptidase $\mathrm{N}$, and the di- and tri-peptide transporter PepT the embryo of the domesticated chicken (Gallus gallus) shows developmental regulation. Poult Sci. (2014) 93:2262-70. doi: 10.3382/ps.2014-03983

25. Yin H, Sumners LH, Dalloul RA, Miska KB, Fetterer RH, Jenkins MC, et al. Changes in expression of an antimicrobial peptide, digestive enzymes, and nutrient transporters in the intestine of E. praecox-infected chickens. Poult Sci. (2015) 94:1521-6. doi: 10.3382/ps/pev133

26. Mehta A, Singh S, Dhawan V, Ganguly NK. Intestinal mucosal lipid peroxidation and absorptive function in Salmonella typhimurium mediated intestinal infection. Mol Cell Biochem. (1998) 178:345-52. doi: 10.1023/A:1006891019115

27. Alteheld B, Evans ME, Gu LH, Ganapathy V, Leibach FH, Jones DP, et al. Alanylglutamine dipeptide and growth hormone maintain PepT1-mediated transport in oxidatively stressed Caco-2 cells. J Nutr. (2005) 135:19-26. doi: 10.1093/jn/135.1.19

28. Yang M, Tao J, Chai M, Wu H, Wang J, Li G, et al. Melatonin improves the quality of inferior bovine oocytes and promoted their subsequent IVF embryo development: mechanisms and results. Molecules (2017) 22:E2059. doi: 10.3390/molecules22122059

29. Fischer TW, Kleszczynski K, Hardkop LH, Kruse N, Zillikens D. Melatonin enhances antioxidative enzyme gene expression (CAT, GPx, SOD), prevents their UVR-induced depletion, and protects against the formation of DNA damage (8-hydroxy-2'-deoxyguanosine) in ex vivo human skin. J Pineal Res. (2013) 54:303-12. doi: 10.1111/jpi.12018

30. Carpentieri A, Marchionatti A, Areco V, Perez A, Centeno V, Tolosa de Talamoni N. Antioxidant and antiapoptotic properties of melatonin restore intestinal calcium absorption altered by menadione. Mol Cell Biochem. (2014) 387:197-205. doi: 10.1007/s11010-013-1885-2
31. Bubenik GA, Ayles HL, Friendship RM, Brown GM, Ball RO. Relationship between melatonin levels in plasma and gastrointestinal tissues and the incidence and severity of gastric ulcers in pigs. J Pineal Res. (1998) 24:62-6. doi: 10.1111/j.1600-079X.1998.tb00367.x

32. Li J, Li J Jr., Zhang SY, Li RX, Lin X, Mi YL, et al. Culture and characterization of chicken small intestinal crypts. Poult Sci. (2018) 97:153643. doi: $10.3382 / \mathrm{ps} /$ pey010

33. Lei XJ, Lee KY, Kim IH. Performance, egg quality, nutrient digestibility, and excreta microbiota shedding in laying hens fed corn-soybean-mealwheat-based diets supplemented with xylanase. Poult Sci. (2018) 97:2071-7. doi: $10.3382 /$ ps/pey041

34. Franchini A, Sirri F, Tallarico N, Minelli G, Iaffaldano N, Meluzzi A. Oxidative stability and sensory and functional properties of eggs from laying hens fed supranutritional doses of vitamins E and C. Poult Sci. (2002) 81:1744-50. doi: $10.1093 / \mathrm{ps} / 81.11 .1744$

35. Yuan ZH, Zhang KY, Ding XM, Luo YH, Bai SP, Zeng QF, et al. Effect of tea polyphenols on production performance, egg quality, and hepatic antioxidant status of laying hens in vanadium-containing diets. Poult Sci. (2016) 95:1709-17. doi: 10.3382/ps/pew097

36. Liu G, Li RX, Guo CQ, Zhao D, Mi YL, Li J, et al. Inhibitory effect of melatonin on formation of the chicken primordial follicles. Pak Vet J. (2017) 37: 263-68.

37. Chowdhury VS, Ubuka T, Tsutsui K. Review: melatonin stimulates the synthesis and release of gonadotropin-inhibitory hormone in birds. Gen Comp Endocrinol. (2013) 181:175-8. doi: 10.1016/j.ygcen.2012.08.005

38. Silk DB, Grimble GK, Rees RG. Protein digestion and amino acid and peptide absorption. Proc Nutr Soc. (1985) 44:63-72. doi: 10.1079/PNS19850011

39. Tümer E, Bröer A, Balkrishna S, Jülich T, Bröer S. Enterocyte-specific regulation of the apical nutrient transporter SLC19 $\left(\mathrm{B}^{0} \mathrm{AT} 1\right)$ by transcriptional and epigenetic networks. J Biol Chem. (2013) 288:33813-23. doi: 10.1074/jbc.M113.482760

40. Huang D, Hu Q, Fang S, Feng J. Dosage effect of zinc glycine chelate on zinc metabolism and gene expression of zinc transporter in intestinal segments on rat. Biol Trace Elem Res. (2016) 171:363-70. doi: 10.1007/s12011-015-0535-9

41. Lamoioui D, Zeman M, Jurcini M. Influence of melatonin on chick skeletal muscle cell growth. Comp Biochem Physiol. (1997) 118:375-9.

42. Drago F, Macauda S, Salehi S. Small doses of melatonin increase intestinal motility in rats. Dig Dis Sci. (2002) 47:1969-74 doi: 10.1023/A:1019696006677

43. Succu S, Pasciu V, Manca ME, Chelucci S, Torres-Rovira L, Leoni GG, et al. Dose-dependent effect of melatonin on postwarming development of vitrified ovine embryos. Theriogenology (2014) 81:1058-66. doi: 10.1016/j.theriogenology.2014.01.032

Conflict of Interest Statement: The authors declare that the research was conducted in the absence of any commercial or financial relationships that could be construed as a potential conflict of interest.

Copyright (c) 2018 Liu, Zhang, Bao, He, Tong, Chen, Ying, Zhang, Zhang and Li. This is an open-access article distributed under the terms of the Creative Commons Attribution License (CC BY). The use, distribution or reproduction in other forums is permitted, provided the original author(s) and the copyright owner(s) are credited and that the original publication in this journal is cited, in accordance with accepted academic practice. No use, distribution or reproduction is permitted which does not comply with these terms. 